\title{
A Response to: Letter to the Editor Regarding A Molecular Signature Response Classifier to Predict Inadequate Response to Tumor Necrosis Factor- $\alpha$ Inhibitors: The NETWORK-004 Prospective Observational Study
}

\author{
Stanley Cohen · Viatcheslav R. Akmaev • Johanna B. Withers • \\ Erin Connolly-Strong
}

Received: October 5, 2021 / Accepted: October 12, 2021 / Published online: November 10, 2021

(c) The Author(s) 2021

Keywords: Rheumatoid arthritis; Precision medicine; Molecular signature response classifier

We wish to thank Dr. Holman, Dr. Keystone, Dr. Choy, Dr. Furst, Dr. Taylor, and Dr. Gaylis for their encouraging comments on our recent publication [1]. Our study combined machine learning and network biology to further refine our molecular signature response classifier (MSRC) test, which predicts non-response to tumor necrosis factor-alpha inhibitors (TNFi) in rheumatoid arthritis (RA). Subsequent analysis of the MSRC across two independent observational cohorts demonstrated its clinical validity, as described in our report.

An issue raised was that in our analysis, demographic characteristics did not differ significantly among patients who responded adequately to TNFi and those who did not. We understand this point. Our observation has

This reply refers to the comment available online at https://doi.org/10.1007/s40744-021-00330-y, https:// doi.org/10.1007/s40744-021-00386-w.

S. Cohen $(\bowtie)$

Internal Medicine, Rheumatology Division, Metroplex Clinical Research Center, Dallas, TX, USA e-mail: arthdoc@aol.com

V. R. Akmaev · J. B. Withers · E. Connolly-Strong Scipher Medicine, Waltham, MA, USA been supported by post hoc analysis of the study, which showed that the MSRC evaluates and stratifies patients with respect to TNFi nonresponse regardless of anti-cyclic citrullinated peptide (CCP) antibody status (unpublished data) (Table 1). While the odds that a patient with an MSRC signature of TNFi non-response would fail to meet ACR50 response criteria at 6 months were approximately three times greater than among those who lacked the signal, we saw no significant difference in odds ratios between patients who were positive or negative for anti-CCP antibodies. This work is based on previously conducted studies and does not contain any new studies with human participants or animals performed by any of the authors.

We appreciate the authors' mention of the high-fidelity heart rate variability study [2], showing that autonomic nervous system (ANS) profiling can be a promising predictor of TNFi response in both RA and psoriatic arthritis. We agree that there exists an opportunity to explore various methods of vagus nerve stimulation (VNS) to promote immunosuppressive response, allowing targeted therapies such as TNFi to be more effective.

Indeed, we view MSRC and ANS/VNS as complementary and potentially synergetic tools within a multifactorial precision medicine approach to treating RA more effectively and rapidly. Precision medicine combines 
Table 1 No significant difference in odds ratios was observed between patients who were positive or negative for anti-CCP

MSRC prediction of TNFi non-response at 6 months, per ACR50 criteria Odds ratio $(95 \%$ confidence interval)

Anti-CCP positive $(n=72)$

$3.5(1.3-9.7)$

Anti-CCP negative $(n=74)$

$3.1(1.2-8.3)$

ACR50 American College of Rheumatology adequate response criteria of 50\% improvement, anti-CCP anti-cyclic citrullinated peptide antibody, MSRC molecular signature response classifier

molecular, physiological, clinical, demographic, behavioral, environmental, and other variables to create tools that can improve the ability to predict and diagnose disease, as well as to estimate prognosis and treatment response [3].

In summary, we believe that our current findings, combined with previous work, show that the MSRC accurately predicts which patients with RA likely will not respond to TNFi therapy. We are optimistic about implementing MSRC clinically as a precision medicine approach to stratify patient groups to therapies most likely to be effective for them, with the goal of improving response earlier in the disease timeline, preventing progression, and reducing the substantial RA disease burden and cost. This article is based on previously conducted studies and does not contain any new studies with human participants or animals performed by any of the authors.

\section{ACKNOWLEDGEMENTS}

Funding. No Rapid Service Fee was received by the journal for the publication of this article.

Authorship. All named authors meet the International Committee of Medical Journal Editors (ICMJE) criteria for authorship for this article, take responsibility for the integrity of the work as a whole, and have given their approval for this version to be published.

Authorship Contributions. Formal Analysis, Investigation, Methodology: all authors; Writing-original draft: ECS; Writing-review \& editing: all authors.
Disclosures. Stanley Cohen: Consultant and investigator for Scipher Medicine. Viatcheslav R. Akmaev, Johanna B. Withers, and Erin Connolly-Strong are full-time employees of and have stock ownership in Scipher Medicine.

Compliance with Ethics Guidelines. This article is based on previously conducted studies and does not contain any new studies with human participants or animals performed by any of the authors.

Open Access. This article is licensed under a Creative Commons Attribution-NonCommercial 4.0 International License, which permits any non-commercial use, sharing, adaptation, distribution and reproduction in any medium or format, as long as you give appropriate credit to the original author(s) and the source, provide a link to the Creative Commons licence, and indicate if changes were made. The images or other third party material in this article are included in the article's Creative Commons licence, unless indicated otherwise in a credit line to the material. If material is not included in the article's Creative Commons licence and your intended use is not permitted by statutory regulation or exceeds the permitted use, you will need to obtain permission directly from the copyright holder. To view a copy of this licence, visit http://creativecommons.org/licenses/by$\mathrm{nc} / 4.0 /$.

\section{REFERENCES}

1. Cohen S, Wells AF, Curtis JR, Dhar R, Mellors T, Zhang L, et al. A molecular signature response classifier to predict inadequate response to tumor 
necrosis factor-alpha inhibitors: the NETWORK-004 prospective observational study. Rheumatol Ther. 2021;8(3):1159-76.

2. Holman AJ, Ng E. Heart rate variability predicts antitumor necrosis factor therapy response for inflammatory arthritis. Auton Neurosci. 2008;143(1-2):58-67.
3. Love-Koh J, Peel A, Rejon-Parrilla JC, Ennis K, Lovett $\mathrm{R}$, Manca $\mathrm{A}$, et al. The future of precision medicine: potential impacts for health technology assessment. Pharmacoeconomics. 2018;36(12):1439-51. 